\title{
IS THE DOCTRINE OF DEVIATION ONLY A HISTORICAL RECORD TODAY?
}

\author{
Sarunas Basijokas
}

\begin{abstract}
As of today the origins of the doctrine of deviation have not yet been firmly established and probably never will be. However, that does not detract from the fact that the doctrine itself has influenced shipping and general contract law and continues to do so even in the modern times. House of Lords judgements in Photo Productions $v$ Securicor, Suisse Atlantique and their interpretations are posing a threat to the continued existence of the deviation doctrine. This paper examines the roots of the doctrine, its importance in sea carriage and intricacies of general contract law. The research findings lead to the conclusion that the law community should not dismiss the notion of deviation as it still remains a doctrine worth preserving.
\end{abstract}

\section{A. INTRODUCTION}

Deviation is a doctrine which has been widely discussed throughout the past two centuries. Different judges viewed the doctrine from a variety of angles and applied it either as an isolated rule of law or as a forming part of a broader picture encompassing general contract law principles. Deviation in simple terms is an unjustified voluntary departure of a ship from the contracted route. At first sight one would not venture to think that such a technical or navigational aspect of carriage of goods by sea could raise legal issues carrying harsh ramifications for parties concerned which to this day have not yet been authoritatively decided. However, that is the reality which resulted in there being a vast array of commentary about the subject raging from academically focused articles in law journals ${ }^{1}$ to divided opinions of the judges deciding deviation cases.

${ }^{1}$ C.P. Mills, 'The future of deviation in the law of the carriage of goods' [1983] Lloyd's Maritime and Commercial Law Quarterly 587; Charles Debattista, 'Fundamental Breach and Deviation in the Carriage of Goods by Sea' [1989] Journal of Business Law 22; John Livermore, 'Deviation, Deck Cargo and Fundamental Breach' (1990) 2 Journal of Contract Law 241; Simon Baughen, 'Does deviation still matter?' [1991] Lloyd's Maritime and Commercial Law Quarterly 70; Martin Dockray, 'Deviation: a doctrine all at sea?' [2000] Lloyd's Maritime and Commercial Law Quarterly 76; J.R. Lee, 'The law of maritime deviation' (1972) 47 Tulane Law Review 155; C.M.C. Cashmore, 'The legal nature of the doctrine of deviation' [1989] Journal of Business Law 492. 
The purpose of this paper is to examine the roots of the deviation doctrine, its relevance and importance in trade by sea, the proper route definition, justified and unjustified deviation. Emphasis will be put on the development of the deviation doctrine with regard to the consequences arising upon the breach of an obligation not to deviate. In this particular part of the paper I will thoroughly look into the most important cases, fundamental breach doctrine and the survival or outcasting of the deviation doctrine in the light of Suisse Atlantique ${ }^{2}$ and Photo Productions $v$ Securicor ${ }^{3}$ cases. The analysis of the breach of the ship owner's obligation not to deviate and the effect it has on the parties will be broken down time-wise into three parts - the first being the time from 1830 s to 1890 , the second part encompassing the period between years 1890 and 1936 and the last part - from 1939 onwards. These precise dates were chosen to mark the most important cases that heavily influenced decision making and legal opinion towards deviation and the effect of breach.

This work on the deviation doctrine is mostly concerned with the foundation of an implied duty of the ship owner not to venture off course. Up until the decision in Davis $v$ Garrett ${ }^{4}$ there was no clear authority which stated that there was an implied duty not to deviate. However, express agreements existed long before Davis $v$ Garrett was decided that usually described the exact route to be taken while on the marine journey. Following parts of this paper are a mixture of both - origins of the duty and general statements concern the overall obligation not to deviate with the implied duty analysis encompassing 1830 s and beyond.

\section{B. Correlation between Deviation and Cargo Insurance}

It should not be surprising that a doctrine attracting such an interest from law academics, practitioners and judges alike stems from marine adventures which took place 300 years ago. Therefore, the origins of the doctrine are undoubtedly ancient dating back to the beginning of the seventeenth century. The doctrine has been around in maritime texts as

\footnotetext{
${ }^{2}$ Suisse Atlantique Soc. d'Armement Maritime SA v N.V. Rotterdamische Kolen Centrale [1967] 1 AC 361.

${ }^{3}$ Photo Productions Ltd v Securicor Transport Ltd. [1980] AC 827.

${ }^{4}$ (1830) 6 Bing 716 (Court of Common Pleas).
} 
early as $1613 .^{5}$ Modern law books describe deviation in a variety of ways with each definition stressing the importance of authorization or lack thereof and voluntariness. Deviation is an '...intentional adoption of a route which differs from the contract route' ${ }^{6}$ John F. Wilson defines it as 'an intentional and unreasonable change in the geographic route of the voyage as contracted" ${ }^{7}$; Martin Dockray describes it as an '....implied term of the contract for the carriage of goods by sea that the carrier will not deviate from the proper route without lawful justification, ${ }^{8}$; according to Scrutton deviation occurs when 'in the absence of express stipulations to the contrary... the owner of the vessel... impliedly undertakes to proceed in that ship by a usual and reasonable route without unjustifiable departure from that route and without unreasonable delay'. "Law academics and judges also agree on the fact that deviation is a breach of contract of carriage. As to the consequences of such a breach there have been harsh debates and erroneous court decisions which will be discussed in the final part of this paper.

As far as the breach of contract is concerned there need not be any conscious breach on the part of the shipowner or master. Deviation occurs when there is a voluntary and unauthorized departure from the agreed or usual / customary course. However, it does not necessarily mean that there is a deviation every time the ship ventures off course. Consequently, there will be no deviation which would amount to a breach of contract when the ship strays off track as a result of other intervening factors like storm, illness of ship's officers or reliance on defective navigational equipment. In Rio Tinto $v$ Seed Shipping ${ }^{10}$ the charterers shipped a cargo at Glasgow for Huelva. The ship's master himself not being in good health, ordered the ship to go in the wrong direction while misreading the information provided by the compass. As the result of such actions the ship stranded on rocks and sustained heavy damage.

\footnotetext{
${ }^{5}$ William Welwod, Abridgement of all Sea-Lawes (Thomas Man 1613) 25.

${ }^{6}$ J. H. S. Cooke et al, Voyage Charters ( $3^{\text {rd }}$ edn, LLP 2007) 251 (hereinafter - Voyage Charters).

${ }^{7}$ J. F. Wilson, Carriage of Goods by Sea (7 $7^{\text {th }}$ edn, Longman 2010) 16.

${ }^{8}$ Martin Dockray, Cases \& Materials on the Carriage of Goods by Sea (3rd edn, Cavendish 2004) 63, 64.

${ }^{9}$ S. C. Boyd, A. S. Burrows and D. Foxton, Scrutton on Charterparties and Bills of Lading ( $21^{\text {st }}$ edn, Sweet \& Maxwell 2008) 231, 232.

${ }^{10}$ (1926) 24 Lloyd's Rep 316.
} 
Per Roche J:

...the essence of deviation [is] that the parties contracting have voluntarily substituted another voyage for that which has been insured. A mere departure or failure to follow the contract voyage or route is not necessarily a deviation, or every stranding which occurred in the course of a voyage would be a deviation, because the voyage contracted for, I imagine, is in no case one which essentially involves the necessity of stranding. It is a change of voyage, a radical breach of contract that is required to, and essentially does, constitute a deviation... ${ }^{11}$

The judge held that the master never intended to leave the contracted route and all he did was to make a mistake as to the compass course due to his ill health. Roche J concluded that the master '...was not on another route; he was on the existing route, although he was out of the proper part of the route which he ought to have followed'. Therefore, there was no substitution or change of voyage which is a vital element when judging whether there was a deviation or not.

The above statements of Roche $\mathrm{J}$ hold a connection with the primary reason for the existence of the deviation doctrine. Law academics and practitioners alike agree that the origins of the doctrine lie in marine insurance. $^{12}$

The doctrine of deviation is like a mirror image of classical marine insurance rules which made a cargo policy void and cargo owner uninsured when a ship deviated from the agreed route. Deviation in such case equals a substitution for a voyage not contracted for by the parties, hence the lapsing of insurance policy which exclusively covered the primary agreed voyage. Judicial authority for such a view can be found in Lavabre $v$ Wilson case where Lord Mansfield held that '...true objection to a deviation is not increase of risk .... It is that the party contracting has voluntarily substituted another voyage for that which has been insured'. ${ }^{13}$ It might very well be so, however, to my mind it boils down to the intentions of the parties. With the introduction of liberty to deviate

11 (1926) 24 Lloyd's Rep 316, 320.

12 Stephen Girvin, Carriage of Goods by Sea (OUP 2007) 309, 310; Michael Bridge, The International Sale of Goods: Law and Practice (OUP 2007) 919, 920; Simon Baughen, Shipping Law (Routledge - Cavendish 2009) 101; A.D. Hughes, Casebook on Carriage of Goods By Sea $\left(2^{\text {nd }}\right.$ edn, Blackstone 1999) 80, 81; J.R. Lee, 'The law of maritime deviation' (n 1) 155.

${ }^{13}$ (1779) 99 ER 185, 189. 
clauses in contracts of carriage the end result would seem to be that the importance of deviation concept has been greatly diminished. However, we should not forget the rulings of Lord Wilberforce in Photo Productions v Securicor and Longmore LJ in Daewoo Heavy Industries Ltd. v Klipriver Shipping Ltd. (The Kapitan Petko Voivoda) ${ }^{14}$ that allow the deviation doctrine to survive if only on a thinnest string. These issues are analysed in detail in the final part of this paper.

\section{Voyage Route}

It is no wonder why deviation is such a frequent occurrence in maritime voyages. Unlike trade by rail or road where there are exact roads or tracks set out for the carriers to stick to, marine travel happens in an open sea. Ships, the crew and cargo carried are always threatened by usually unforeseeable maritime perils that can cause havoc at any stage of the voyage. During the course of shipping history ocean travelers have discovered certain trade routes that avoid known marine dangers, established customs to use certain short-cuts and bunkering ports while on the route. These happenings are very important in considering the voyage route a ship has to take in order to comply with the deviation rules. Unless the charterparty or a bill of lading dictates the route to be followed from the loading port to the discharge port the master's obligation is to follow the usual and customary course. It has been held in Achille Lauro $v$ Total $^{15}$ that generally the usual route is to be the direct geographical route. There is no denying that it is a clear presumption, however we should not forget that all legal presumptions can be rebutted. As the direct geographical route very frequently differs from the usual customary course, parties to the dispute can put forward evidence of a shipping line, trade route, usual bunkering locations or a commercial custom to go around certain dangerous, unknown areas that would rebut the geographically based presumption. Judicial approval for such a view is to be found in Reardon Smith Line v Black Sea and Baltic General Insurance ${ }^{16}$ where a ship was chartered to carry a cargo from Ponti in the Black Sea to the United States of America. The vessel grounded and damaged its cargo at Constanza where she had gone to refuel. The

\footnotetext{
${ }_{15}^{14}$ [2003] 2 Lloyd's Rep 1, [13]-[15].

${ }^{15}$ [1968] 2 Lloyd's Rep. 247, 251.

${ }^{16}$ [1939] AC 562 (HL).
} 
charterers based their claim on the fact that by going to Constanza the ship had deviated from her contractual route.

Per Lord Porter:

In each case therefore when a ship is chartered to sail or when a parcel is shipped upon a liner sailing from one port to another, it is necessary to inquire what the usual route is. In some cases there may be more than one usual route... It is not the geographical route but the usual route which has to be followed, though in many cases the one may be the same as the other. But the inquiry must always be, what is the usual route, and a route may become a usual route in the case of a particular line though that line is accustomed to follow a course which is not that adopted by the vessels belonging to other lines or to other individuals. It is sufficient if there is a well known practice of that line to call at a particular port. ${ }^{17}$

The House of Lords held that even if there had only been a short usage of Constanza as a bunkering spot, it was still enough to establish it as a usual bunkering location for ships on that particular route. What is significant about this decision is that it expands the scope of deviation doctrine in a sense that parties are not constrained to the direct geographical route between the ports and can make commercial use of trade lines which are only known to a few. This is not to say that shipowners can create their own routes as they go, however a customary route undeniably has to start with someone sensibly using a fueling point or intermediate port for supplies. Support for the view that it all depends on specific circumstances can be found in the decision of the Court of Appeal in James Morrison Ltd. $v$ Shaw, Savill and Albion ${ }^{18}$ where Swinfen Eady L.J. was of the opinion that it is impossible to have a 'hard and fast rule' by which you could determine whether a certain stop point was on the course of the voyage or not. He asserts that in such cases all circumstances like the 'size and class of the ship', 'nature of the voyage', 'usual and customary course', 'the natural and usual ports of call', 'the nature and the position of the port in question' have to be taken into account. Therefore, ship owners who are aware of the conditions described above have more wiggle room when on a voyage to reasonably

\footnotetext{
${ }_{17}^{17}[1939]$ AC 562 at 584, 585.

18 [1916] 2 KB 783.
} 
deviate in order to make the marine journey more safe, efficient or profitable.

The notion of reasonableness when judging the voyage route had so greatly influenced the courts that in the majority of cases substance always had primacy over the printed clause. As per William Tetley and Bruce Cleven '...the clause [was] of less importance than the actual deviation'. ${ }^{19}$ That was clearly evidenced in G.H. Renton \& Co. Ltd. $v$ Palmyra Trading Corp. ${ }^{20}$ In that case the bill of lading provided for an alternative port of discharge in case of strikes, quarantine, labour troubles, lockouts or similar disturbances. Lord Morton of Henryton held that the master had not deviated if he had reasonably chosen another port in order to perform the contract. The learned provision only gave the master freedom to choose another port if and when faced with the named disturbances in the contracted port of discharge. ${ }^{21}$

\section{Liberty to Deviate Clauses}

As evidenced above deviation is a very common happening in ocean travel. Throughout the history ship owners and masters have always been eager for more freedom whilst at sea. It turned out that their attempts to achieve that had not been in vain as liberty to deviate clauses were introduced in charterparties and bills of lading. As a consequence, the common law duty not to deviate could then be contractually altered to allow certain deviations from the agreed route. Not surprisingly, ship owners had seen this as a very good opportunity to make use of such stipulations in order to permit them to fit the voyage to their personal preferences. The principle that English private law is based on freedom of the parties to agree the content of their contractual relations provided a fertile ground for ship owners' creativeness. In the end result some liberty to deviate clauses became so wide in scope that the master at sea could call at any port in any order. For example, Gencon Charter (1994 revised edition) includes a deviation clause stating that 'the vessel has liberty to call at any port or ports in any order, for any purpose...'. ${ }^{22}$ A very similar

\footnotetext{
${ }^{19}$ William Tetley and Bruce Cleven, 'Prosecuting the voyage' (1971) 45 Tul. L. Rev. 810,812 .

${ }^{20}$ [1956] 2 Lloyd's Rep 379.

21 ibid 391.

${ }^{22}$ Gencon Charter 1994 clause 3.
} 
wording can also be found in Asbatankvoy form. ${ }^{23}$ 'The apogee' as Simon Baughen ${ }^{24}$ called it of the widest liberty clause is to be found in Connolly Shaw v A/S Det Nordefjelkske D/S ${ }^{25}$ where the parties created a clause which read that the ship can '...proceed to or return to and stay at any ports or places whatsoever... in a contrary direction to or out of or beyond the route... in any order... backwards or forwards... or for any purpose whatsoever'. Such clauses in bills of lading and charter parties undeniably created almost unlimited discretion upon the ship owners to venture off course. This unbalance in the rights and duties of the parties was restricted by English court decisions in Leduc $v$ Ward $^{26}$ and Glynn $v$ Margetson. $^{27}$

In Leduc $v$ Ward the direct route to the port of discharge was ignored and the ship strayed off course sailing about 1200 miles in the wrong direction. ${ }^{28}$ Lord Esher's judgement stressed out that even if the parties contracted to give the master liberty to sail to any ports in any order, it was always a question of interpretation of 'mercantile expression used in a mercantile document'. ${ }^{29}$ Generally, mercantile transactions are conducted between business people in the realms of business common sense. The more the intention of the parties flouts business common sense the less it is possible that parties have actually meant it. To my mind, that was the reason Lord Esher came to the conclusion that even if the contractual provision includes permission for the ship to sail to any ports '...she would only be entitled to call at such ports in their geographical order [and] ...that the ports must be ports substantially on the course of the voyage'. ${ }^{30}$ What conclusions could be drawn from this decision? It would seem that the opening for ship owners to greatly manipulate the conditions of the voyage had been shut. Lord Esher's approach was taken even further in the House of Lords decision Glynn v Margetson. Charles

\footnotetext{
${ }^{23}$ Clause 20 (vii).

${ }^{24}$ Baughen, 'Does deviation still matter?' (n 1) 76, 77.

25 (1934) 49 Lloyd's Rep. 183.

26 (1888) 20 QBD 475 (Court of Appeal).

27 [1893] AC 351 (House of Lords).

28 Dockray, Cases \& Materials on the Carriage of Goods by Sea (n 8) 69.

${ }^{29}$ Leduc v Ward (1888) $20 \mathrm{KBD} 482$.

${ }^{30}$ ibid.
} 
Debattista $^{31}$ is of the opinion that the rule put forward by the judges in Glynn v Margetson is one of the 'devices' that 'protects the buyer against the abuse by the carrier of a liberty to deviate'. In the case in question the parties had contracted for a very wide liberty clause which covered ports in any rotation in the listed specific seas. ${ }^{32}$ The ship, on leaving the loading port, went to the opposite direction and not towards the discharge destination. Lord Herschell and Lord Halsbury both agreed that primacy has to be given to the main purpose of the contract. In that case it was the carriage of perishable cargo. ${ }^{33}$ Therefore, such a deviation that would not accord with the way perishable cargo is traded would not be acceptable as it would frustrate the whole purpose of the voyage. This is exactly what had happened in the case in question as the cargo of oranges was damaged on discharge due to the delay in proceeding to the agreed destination. Cumulative effect of both court decisions suggests that generally even if there is a wide liberty to deviate clause a ship is only permitted to call at ports, without unreasonable delay which could raise a possibility of frustration, which in a business perspective could be said to be in between the loading and discharge port. Therefore, it can be said that Charles Debattista was on the right track to call the Glynn $v$ Margetson rule one of the 'devices' ${ }^{34}$ in the law of carriage of goods by sea against the exploitation of liberty clauses.

A strange approach was taken in James Morrison Ltd. $v$ Shaw Savill and Albion Company. ${ }^{35}$ There it was held that a certain port only 54 miles off course was not an intermediate port and, therefore, sailing to it was an unreasonable deviation. Authors of Voyage Charters expressed the opinion that in this case the Court of Appeal judges 'seem to have been influenced by the fact that [Le Harve] was not a usual port of call for ships... and interpreted the liberty clause as being intended merely to permit the ship to call at ports usually visited ${ }^{36}$ I would agree with the expressed view that this construction of the contract terms divests the liberty to deviate clause of most of its importance as then the only ports

\footnotetext{
${ }^{31}$ Charles Debattista, The Sale of Goods Carried by Sea, (2 ${ }^{\text {nd }}$ edn, Butterworths 1998) 143-145.

32 [1893] AC 351 (HL), 353.

33 ibid 355, 357.

${ }^{34}$ Debattista, The Sale of Goods Carried by Sea (n 31) 143.

${ }^{35}$ [1916] 2 KB 783.

${ }^{36}$ Cooke et al, Voyage Charters (n 6) 258.
} 
of call would be the ones that are used by the majority of ships on that particular shipping line. I am of the opinion that James Morrison has to be read cautiously as it ignores the dicta in Glynn v Margetson and Leduc $v$ Ward where it can be said that unreasonable deviation is only when a ship goes in the wrong direction or disregards the nature of the cargo carried. The correct view has to be that of Swinfen Eady L.J. ${ }^{37}$ that it all depends on specific circumstances. That raises a debate whether the Court of Appeal was right in James Morrison in saying that 54 miles is so far off the shipping business practice to call at ports 'substantially ...on the named voyage ${ }^{38}$ that it constitutes an unreasonable deviation. My position would be those 54 miles were most probably insignificant when taking the whole trip from New Zealand to London into account.

Simon Baughen in his article 'Does deviation still matter?' asked an interesting question whether liberty clauses can be constructed as to cover every voyage irrespective of the destination and the nature of the cargo carried. ${ }^{39}$ He based his view on the speech of Atkin, L.J. in The Cap Palos $^{40}$ case where he suggested that a specifically worded exception clause might exclude ship owner's liability for any breach of contract including a deviation. This statement can be said to contradict with the tendency in English law to limit the use of exclusion clauses, especially the all-encompassing ones that exclude all types of liability. Main statutory tools designed to restrict the use of exclusion clauses are the Unfair Contract Terms Act 1977 (hereinafter - UCTA 1977) and the Unfair Terms in Consumer Contracts Regulations 1999 (hereinafter UTCCR 1999). It would be all plain sailing if those Acts had full effect on contracts of carriage. Unfortunately (or fortunately from the ship owner's point of view), UCTA 1977 applies only to certain aspects of shipping contracts. ${ }^{41}$ While section 2 of the UCTA 1977 greatly restricts the use of exemption clauses that limit negligence liability, section 2(c) in Schedule 1 of the UCTA 1977 states that only section 2(1) extends to 'any contract for the carriage of goods by ship or hovercraft'; 'but subject to this sections 2 to 4 and 7 do not extend to any such contract except in

\footnotetext{
37 James Morrison Ltd. v Shaw Savill and Albion Company [1916] 2 KB 783795.

${ }^{38}$ As per Leduc $v$ Ward (1888) 20 QBD 482.

${ }^{39}$ Baughen, 'Does deviation still matter?' (n 1) 77.

${ }^{40}$ (1921) 8 Lloyd's Rep 309, 312.

${ }^{41}$ Richard Stone, The Modern Law of Contract ( $9^{\text {th }}$ edn, Routledge 2011$)$ 235, 236.
} 
favor of a person dealing as a consumer'. Similar restricting provisions are to be found in section 3 in Schedule 1 of the UCTA 1977. In result any contract for the carriage of goods by sea is only subject to s. 2(1) of the UCTA 1977 which covers death or personal injury resulting from negligence. As these contingencies have no connection with unreasonable deviation and since in almost most cases neither party to a contract for the carriage of goods by sea are consumers, it is very unlikely that UCTA 1977 poses any threat for the drafting of wide liberty clauses in charter parties and bills of lading.

UTCCR 1999 unlike UCTA 1977 apply to all types of contractual provisions, not just the clauses that limit liability. What is more, UTCCR 1999 do not apply to any statement that is 'individually negotiated ${ }^{42}$ and generally apply only to 'unfair terms in contracts concluded between a seller or a supplier and a consumer'. ${ }^{43}$ The main reason for enforcing such a statutory intervention was to regulate standard consumer contracts. Even if there are certain printed forms of charter parties and bills of lading, contracts of affreightment are also based on the terms specifically negotiated between the parties. We should also not forget that contracts for the sale of goods carried by sea do not fall under the heading 'consumer contracts'. Taking that into account it is safe to say that terms in contracts of affreightment are not subject to the harshness of the UTCCR 1999 regime.

Where does that leave us? In the world where ship masters can sail to any part of the ocean without having any regard in the main object of the contract? To my mind, even if UCTA 1977 and UTCCR 1999 do not figure in contracts for the carriage of goods by sea, business common sense has to be taken as a guideline for not allowing exclusion clauses in contracts that would give one of the parties complete freedom to negate the purpose of that agreement. Another way of fighting such a mischief would be to follow the view of Charles Debattista ${ }^{44}$ that there is always room for the contra proferentem rule of construction, in other words 'the secret weapon' as Lord Denning called it in Mitchell (George)

\footnotetext{
${ }^{42}$ UTCCR s 5(1).

43 ibid s 4(1).

${ }^{44}$ Debattista, 'Fundamental Breach and Deviation in the Carriage of Goods by Sea' (n 1) 22-36.
} 
(Chesterhall) Ltd. v Finney Lock Seeds Ltd ${ }^{45}$. The contra proferentem rule should come into play when the liberty clause has been drafted by the ship owner in which case it would be construed against him. The very needed cherry on the top can be found in Lord Diplock's dicta in Photo Productions $v$ Securicor where he concluded that no matter how far reaching is the freedom to contract for any exclusions or liberties, the overriding factor is for the agreement to '...retain the legal characteristics of a contract'. ${ }^{46}$

\section{E. Permissible Deviations at Common Law and under the HAgUe-VISBY Rules ${ }^{47}$}

No matter how strict the law generally is, there is always room for more exceptions. Historically, the strictness of the deviation doctrine has always been controlled by the rules of common law. These rules differ from the liberty to deviate clauses which are contractual in nature in that the common law rules protect the lives of people at sea, the ship and the cargo carried. Under the common law regime deviation is considered to be lawful when saving human life and when deviating so that danger to the ship or cargo could be avoided.

The leading case which states that deviating for the purpose of saving human life is justified is Scaramanga v Stamp. ${ }^{48}$ In this case a ship Olympias had to carry a cargo from Cronstadt to Gibraltar. After sailing for some time the crew spotted another ship which was in distress. A significant point in the case was that the ship itself was not in any danger of becoming a total loss. The crew onboard the Olympias could have easily taken off the crew from the broken down ship. Instead of doing that, Olympias towed the disabled ship into a port of safety in order to acquire salvage. Cockburn CJ came to a conclusion that in this particular case the deviation had two purposes.

\footnotetext{
${ }^{45}$ [1983] 1 All ER 108.

${ }^{46}$ [1980] AC 827, 850.

${ }^{47}$ Protocol to Amend the International Convention for the Unification of Certain Rules of Law Relating to Bills of Lading (the 'Visby Amendments') (adopted 23 February 1968, entered into force 23 June 1977) 1412 UNTS 127 (Hague-Visby Rules).

${ }^{48}$ (1880) 5 CPD 295.
} 
Per Cockburn CJ:

...deviation for the purpose of saving life is protected, and involves neither forfeiture of insurance nor liability to the goods' owner... And, as a necessary consequence of foregoing, deviation for the purpose of communicating with a ship in distress is allowable, inasmuch as the state of the vessel in distress may involve danger to life. On the other hand, deviation for the sole purpose of saving property is not thus privileged, but entails all the usual consequences of deviation... If, therefore, the lives of the persons on board a disabled ship can be saved without saving the ship, as by taking them off, deviation for the purpose of saving the ship will carry with it all the consequences of an unauthorized deviation. ${ }^{49}$

Without doubt the reasoning is based on the fundamental concept of mankind to help one another in all life-threatening situations. It is a moral duty that each of us have to fulfill. That is why Cockburn CJ also asserted that 'there is neither injustice nor hardship in treating both the merchant and the insurer as making their contracts with the ship owner as subject to this exception to the general rule of not deviating from the appointed course'. ${ }^{50}$ He concluded that because the grounds for justifying deviation for the purpose of saving other property at sea are not so pivotal and are basically based on a vague lucrative gain in favor of the ship owner, such a deviation is not accepted under the common law regime.

The common law rule to save life is also strengthened by the fact that legislative intervention has been introduced for the purpose of imposing an obligation to save human life whilst at sea. International Maritime Organization (hereinafter - IMO) which was established by the United Nations in year 1958 is the most active international body in the field of maritime law, more precisely in safety of shipping and prevention of water pollution. ${ }^{51}$ IMO imposed international standards of shipping safety by introducing the International Convention for the Safety of Life at Sea 1974 (SOLAS) ${ }^{52}$ and International Convention on Maritime Search

\footnotetext{
${ }^{49}$ [1880] 5 CPD 295, 304.

${ }^{50}$ ibid.

${ }^{51}$ International Maritime Organization 'Introduction to IMO'

$<$ http://www.imo.org/About/Pages/Default.aspx> accessed 20 August 2012.

${ }^{52}$ International Convention for the Safety of Life at Sea 1974 (adopted 1 November 1974, entered into force 25 May 1980) 1184 UNTS 3 (SOLAS).
} 
and Rescue 1979 (SAR) ${ }^{53}$. The significant element about these initiatives is that $\mathrm{SOLAS}^{54}$ as well as $\mathrm{SAR}^{55}$ include a general obligation upon the masters of the ships to proceed in order to help those in serious danger.

Similar statutory obligations are imposed by the Merchant Shipping Act 1995 upon the masters of the ships in the territorial waters of the United Kingdom. Section 93 applies to both local and foreign ships and provides that 'master of a ship...on receiving a signal of distress...shall proceed with all speed to assistance of the persons in distress'.

In relation to the analysis above, it is important to note that deviation in order to save other property at sea is not justified under the regime of common law, however if the danger is imminent to the carrying ship the master is permitted to go off course for the purpose of ensuring the safety of the ship and the cargo carried. ${ }^{56}$ What is more, such danger has to be not only imminent, but also of a 'reasonably permanent nature'. ${ }^{57}$

The amount of weight that is put on the allowances to deviate for the purpose averting danger to the lives of the crew, the ship and its cargo can be seen in Kish $v$ Taylor $^{58}$. The reason the ship became unsafe was because the charterers did not provide a complete cargo and the master in attempting to avoid dead freight sought out additional cargo which in result made the ship unseaworthy. Lord Atkinson agreed that these actions by the master were a breach of contract, however the deviation in order to take refuge and have the cargo restowed was held to be lawful because it was a deviation 'necessary to save his ship and the lives of his crew' ${ }^{59}$ Even if this deviation did not end the contract, the charterers still retained the right to claim damages for the breach of contract. The broad approach of Kish v Taylor was challenged in Monarch Steamship v Karlshamns Oliefabriker ${ }^{60}$ where Lord Porter asserted that 'deviation necessarily made to remedy unseaworthiness does not amount to

\footnotetext{
${ }^{53}$ International Convention on Maritime Search and Rescue 1979 (adopted 27 April 1979, entered into force 22 June 1985) 1403 UNTS (SAR).

${ }^{54}$ SOLAS 2004, chapter 5.

${ }^{55}$ SAR s.2.1.10: 'Parties shall ensure that assistance be provided to any person in distress at sea'.

${ }^{56}$ Girvin, Carriage of Goods by Sea (n 12) 313.

${ }^{57}$ ibid.

${ }^{58}$ [1912] AC 604 (HL).

${ }^{59}$ ibid 618.

${ }^{60}$ [1949] AC 196.
} 
unjustifiable deviation...unless it is established that the owners knew of the vessel's state on sailing'. ${ }^{61}$ In that particular case there was no such evidence, however if it were otherwise - the deviation would have been held unjustified. This stems from the fundamental principle of law that no one can profit from his own wrongful act.

Common law regime is slightly relaxed under the Hague, and the Hague-Visby rules. The Hague and the revised Hague-Visby rules were implemented in 1924 and 1968 respectively to achieve uniformity in documentation used in the trade by sea. These rules have been incorporated as a Schedule 1 to the Carriage of Goods by Sea Act 1971. Newest amendment to the Carriage of Goods by Sea Act made in 1992 has effect without prejudice to the application of Hague/Hague-Visby rules. $^{62}$ Therefore, where the Carriage of Goods by Sea Act applies, article IV(4) of the Hague/Hague-Visby rules states the ambit of permitted deviation. It provides that '...deviation in saving or attempting to save life or property at sea or any reasonable deviation shall not be deemed to be an infringement or breach of...the contract of carriage'. It differs from the common law concept in that it is permissible to deviation for the purpose of saving other property as well as any other 'reasonable deviation'. That means the justified deviation doctrine under Hague/Hague-Visby rules encompasses a broader view of what amounts to a reasonable deviation. A clear example of the relaxed approach is shown in Stag Line v Foscolo Mango and Co where deviation in order to land two engineers who were making sure that the ship engine was working efficiently was held to be reasonable. ${ }^{63}$

\section{F. EFFECT OF BREACH}

The above analysis of the intricacies of the deviation doctrine, its origins and what amounts to justified or unjustified deviation is important in discussing the legal effects of an unreasonable deviation. The issue of what happens after deviation occurs has been an area of maritime law cloaked with uncertainty. As has been said above, in the times when wide liberty clauses and held covered clauses were still a thing of the future unreasonable deviation always resulted in a lapsed cargo insurance

\footnotetext{
${ }^{61}$ [1949] AC 196, 212.

62 s 5(5) Carriage of Goods by Sea Act 1992.

${ }^{63}$ [1932] AC 328, 343.
} 
policy. In the words of C.P. Mills that 'upon deviating the carrier was said to become an insurer of the goods' ${ }^{64}$ Therefore, the owner of a deviating ship immediately became strictly liable for the cargo carried. In consequence, all terms in the contract of carriage in favor of the ship owner (exclusion clauses, liability limits, liberty clauses) were held not to apply from the moment of deviation.

\section{Years 1830 - 1890}

These years were both fortunate and unfortunate for the development of the deviation doctrine. Both fortunate and unfortunate events are essentially connected with one case - Davis $v$ Garrett. ${ }^{65}$ The deviation doctrine in the form of express provisions in carriage contracts existed long before Davis $v$ Garrett, however this particular case acknowledged that a sea carrier has an implied duty to follow usual and customary course towards the final port of discharge. Furthermore, this case also stated that the ship owner was liable for the losses that occurred during a deviation. The unfortunate part of the case in question was that the ship owner did not argue that there were standard exclusions in the contract as to the contingencies on the voyage. In result, this case neither dealt with how the exclusion clauses function after the deviation, nor what happens to the contract once an unreasonable deviation occurs. Martin Dockray concurs that Davis $v$ Garrett is a case of limited significance as the approaches presented were not 'a novelty' in the law at that particular time and because there are no clear explanations as to the conclusions made, especially why the court believed that there should be an implied obligation not to deviate. ${ }^{66}$ What is more, the case also did not rule on who would be held liable for losses arising after the ship regained the course. This issue still remained uncertain even in 1880 as the judge did not even consider such a possibility. ${ }^{67}$

\section{Years 1890 - 1936}

This period brought new light to the deviation doctrine. That light is very dim with regard to the modern developments in breach of contract and

\footnotetext{
${ }^{64}$ Mills, 'The future of deviation in the law of the carriage of goods' (n 1) 587.

${ }^{65}$ (1830) 6 Bing 716, 725.

${ }^{66}$ Dockray, Cases \& Materials on the Carriage of Goods by Sea (n 8) 63, 64.

${ }^{67}$ Scaramanga v Stamp (1879) LR 4 CPD 316, 321.
} 
nowadays might survive only as a historical fact, however the importance of the case stems from the fact that it was a step forward in the advancement of the deviation doctrine no matter how far off course. The first of the two core decisions in this period is Balian and Sons $v$ Joly, Victoria and Co. Ltd. ${ }^{68}$ In this case, instead of making the issue of breach more clear, Lord Esher, despite his opening remarks saying that the 'case is clear', brought even more confusion into the matter. On the up side, the Court of Appeal held that the unjustified deviation doctrine deprived the carrier of the rights to enforce the exception clauses contained in the contract of carriage. That would have been a sensible step forward for the deviation doctrine if not for the reasoning of Lord Esher which was based on the fact that deviation constitutes a change of voyage as contracted and thus after the deviation 'the whole bill of lading [was] gone'. ${ }^{69}$ Lord Justice Fry and Lord Justice Lopes concurred. The remarkable thing about Lord Esher's view is that it was inconsistent with the orthodox law at that time. Freeman $v$ Taylor ${ }^{70}$ and Davidson $v$ Gwynne ${ }^{71}$ are good examples that when Balian was decided the established view was that the deviation in question had to deprive the cargo owner of the whole benefit of the contract in order for him to gain the privilege to end the contract. ${ }^{72}$

Things did not turn to the bright side with the decision in Joseph Thorley Ltd $v$ Orhis Steamship $\mathrm{Co}^{73}$ either. To my mind, there is a very simple answer to why Orhis Steamship did not develop the doctrine in the correct direction. As can be seen from the judgments of J.A. Hamilton, K.C, Collins M.R., Cozens-Hardy L.J. and Fletcher Moulton L.J. ${ }^{74}$ the unfortunate fact was that the judges rightly held Balian as authority in Orhis Steamship Co for two main reasons. Firstly, the facts of both cases were almost indistinguishable and, secondly, Balian was an earlier Court of Appeal decision that the subsequent court could not have not moved away from. In Orhis Steamship damage to the goods was done by the stevedores in the process of discharging the ship. The bill of lading contained a broad exception clause exempting the ship owners from

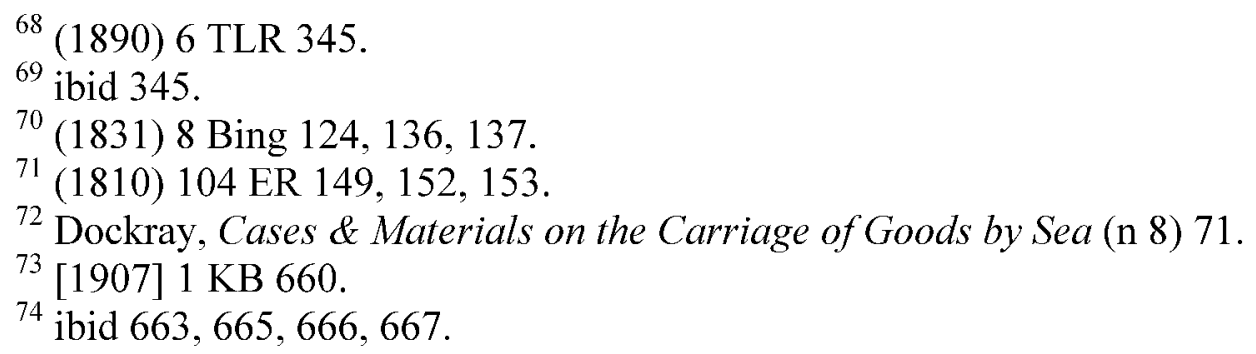


liability for loss arising from '....any act, neglect, or default whatsoever of the...stevedores.... ${ }^{75}$ All the judges in Orhis Steamship were of the opinion that the obligation not to deviate has an effect of a condition. Collins M.R. ${ }^{76}$ drew parallel lines between the newly introduced 'condition' not to deviate with that of seaworthiness obligation in a voyage charter. He stressed out that a breach of an obligation not to deviate goes to 'the root of the contract' and '...its performance is a condition precedent to the right of the ship owner to put the contract in suit'. In simple terms that would mean the contract is displaced as from inception including any exception or limitation clauses. This is what English law would call rescission ab initio. As the law stands right now this was neither the correct terminology, nor the right approach.

The established general rule of contract law is that where a breach of term is considered to be a repudiatory breach, all terms of the contract remain intact up until the innocent party accepts the repudiation. ${ }^{77}$ Unaccepted repudiation does not have any legal effect. The toughest question which still baffles the common law experts is whether this general rule applies to deviation cases. If it does, then the ship owner has the right to rely on any terms in his favor until the date of the election to accept the repudiation, including any exception or liberty clauses. However, as we can clearly see the reasoning in Orhis Steamship was based on entirely different grounds and thus departed from the general contract law. Striking feature of this case is that it has never been overruled. Two years after Orhis Steamship the stridency of the 'condition precedent' rule was given full effect in International Guano en Superphospaten-Werken $v$ Robert MacAndrew \& Co Ltd where the shipowners were not allowed to rely on exception clause as to the damage done before the unreasonable deviation occurred. ${ }^{78} \mathrm{~A}$ 'further extreme' as Stephen Girvin put $\mathrm{it}^{79}$ can be found in a case of US Shipping Board $v$ Bunge $y$ Born $^{80}$ where the terms concerning demurrage fees on discharge were said to be ineffective because the contract had been avoided ab

\footnotetext{
75 ibid 661.

${ }^{76}$ ibid 667.

77 J. H. S. Cooke et al, Voyage Charters (n 6), 264

${ }^{78}$ [1909] 2 KB 360.

${ }^{79}$ Girvin, Carriage of Goods by Sea (n 12) 317.

${ }^{80}$ (1925) 42 TLR 174.
} 
initio. The analysis of the cases decided between the years $1890-1936$ proves that in this period a breach as to the voyage course, no matter how trivial, was considered to be of fundamental importance and thus meant that the contract automatically came to an end depriving the ship owner of any right to rely on terms which were drafted in his favor. These views were not on par with the practice of including held covered clauses in cargo insurance contracts providing for cover in exchange for additional premium as well as not justified enough to hold the ship owner liable for events which had happened before the change of course. It goes without saying that the law was in need of reform.

\section{1936 and Beyond}

It is rather unfortunate to see that not even the later case of Hain Steamship Co Ltd $v$ Tate \& Lyle Ltd ${ }^{81}$ solved all the problems. Nevertheless, this case was the first case where the House of Lords thoroughly analysed the deviation doctrine. Tregenna, the chartered ship, was to load a cargo of sugar from Cuba and San Domingo. After loading at two Cuban ports Tregenna proceeded towards the port of Queenstown whilst awaiting for the nomination of the San Domingo port. The nomination was not delivered to the master of the ship due to a fault of the shipowner's agents. Once the charterers spotted the error, the master of the ship was immediately ordered back to San Domingo to load the remaining cargo. On leaving the last loading port the ship ran aground and lost part of the cargo. The crucial finding of the House of Lords in his case was that even a trivial deviation constituted a breach of 'such a serious character' that it went to 'the root of the contract' and that the innocent party was entitled 'to declare himself as no longer bound by any of the contract terms'. ${ }^{82}$ In result, Hain introduced a modified concept of repudiatory breach where the innocent party could either elect to treat the contract as at end and sue for damages or keep it alive by affirming it. At first sight it might seem like the repudiatory or fundamental breach doctrine that is effective today, but deeper analysis reveals core differences. Firstly, even though Hain accepted that after the deviation the contract does not automatically come to an end, once the choice to

${ }^{81}$ (1936) 55 Ll. L. Rep. 159.

82 ibid $173,174$. 
end the contract is made by the innocent party, the contract is held as not to have existed. This does not come into terms with general contract law as it is established today, because according to the orthodox view the primary obligations under the contract continue up until the moment the innocent party chooses to accept the repudiation. Secondly, Lord Atkin asserted that even if the deviation was immaterial to the entire voyage and had not had any effect on the condition of the cargo, it still amounted to a fundamental breach of contract. Such a statement does seem to support the nowadays orthodox view that fundamental breach is one which deprives the innocent party of the whole benefit of the contract. ${ }^{83}$ That raises a question whether a trivial deviation which did not contribute to the damage of the cargo could amount to a fundamental breach of contract. To my mind, in the majority of cases such a deviation would not be relevant. Therefore, instead of formally treating every deviation as a fundamental breach, emphasis should be put on the construction of the terms of the contract and the severity of the breach. ${ }^{84}$

What the judges in Hain tried to introduce is the now forgotten fundamental breach doctrine which was so stubbornly argued by Lord Denning. In Suisse Atlantique ship owners argued that demurrage clause could not be relied upon by the charterers as the breaches of contract which caused the delays constituted a fundamental breach. ${ }^{85}$ Viscount Dilhorne, Lord Hodson, and Lord Wilberforce clearly reasoned that there is no fundamental breach as a rule of law and that the application of exclusion clauses is subject to the construction of the contract as a whole. ${ }^{86}$ The outcome of Suisse Atlantique was radically misinterpreted by Lord Denning in non-deviation case of Harbutt's Plasticine Ltd. $v$ Wayne Tank and Pump Co. Ltd where it was held that there are certain fundamental breaches of contract that end the contract and cancel all exclusion clauses available for the party in breach. ${ }^{87}$ Lord Denning's view and erroneous interpretation of Suisse Atlantique only survived until the House of Lords reached a decision in Photo Productions $v$ Securicor.

\footnotetext{
${ }^{83}$ Hong Kong Fir Shipping Co. Ltd. v Kawasaki Kisen Kaisha [1962] 2 QB 26, 66.

${ }^{84}$ H. G. Beale, Chitty on Contracts (30th edn, Sweet \& Maxwell 2008) 928, 929.

${ }^{85}$ [1967] 1 AC 361.

${ }^{86}$ ibid 392, 399, 405, 410, 425, 431, 432.

${ }^{87}$ [1970] 1 QB 447.
} 
There Lord Wilberforce ${ }^{88}$ rejected Harbutt's view and pointed out that the reasoning of Lord Denning in that judgment was 'radically inconsistent with the Suisse Atlantique case'. ${ }^{89}$ The judges in Photo Productions $v$ Securicor denied that there is a rule of law as to fundamental breach, reaffirmed the view adopted in Suisse Atlantique in that everything depends on the true construction of the contract terms and that a breach does not automatically deny reliance on limitation clauses. Another important finding in the case was that no term can be regarded as fundamental, unless it is a condition agreed upon by both parties. ${ }^{90}$

It might rightfully seem that after Photo Productions $v$ Securicor there should not be any problems with the effect of breach in deviation cases. However, that is a wrong assumption for two main reasons. Firstly, Photo Productions $v$ Securicor had nothing to do with carriage of goods by sea, ships or deviation for that matter. Secondly, the core reason for stating that fundamental breach doctrine is a thing of the past was the statutory intervention in 1977 in the form of UCTA 1977. As mentioned before, this Act allowed for exception clauses to be applied with reference to the test of reasonableness. With regard to limited application of UCTA 1977 to carriage of goods contracts there seems to be a broken link between the still not overruled Hain and Photo Productions $v$ Securicor. A further difficulty is presented by the fact that the outcasting of fundamental breach doctrine is to be found in a case dealing with general contract law principles. These facts did not slip past Lord Wilberforce. In Photo Productions $v$ Securicor he argued that the Harbutt's case seems to support the doctrine adopted in Hain. And while that may be true, deviation cases cannot be read as laying down general principles of contract law that differ from the views exposed in Photo Productions $v$ Securicor. Conversely, Lord Wilberforce was of the opinion that Hain and the doctrine adopted to deviation cases can be regarded as 'body of authority sui generis with special rules derived from historical and commercial reasons'.91 One might ask what led Lord Wilberforce to such a conclusion? For a body of law to be considered autonomous there has to be certain core elements that distinguish it from

\footnotetext{
${ }^{88}$ [1980] AC 827, 841 [A]-[G].

89 ibid 844 .

${ }^{90}$ ibid 849 .

${ }^{91}$ ibid 845.
} 
other sources of law. A vague statement of 'historical and commercial reasons' might have been enough if Lord Wilberforce had provided a deeper explanation into why the rules of deviation have to be preserved. However, such an explanation can be found in law literature. Professor Brian Coote argues that deviation cases essentially deal with bailment obligations and that throughout the twentieth century the law has muddled together deviation rules, discharge for breach and the doctrine of fundamental breach. ${ }^{92}$ According to Brian Coote the only 'true explanation' for the deviation rules lies in the relationship between the bailor and the bailee. The bailee can only rely on the contract terms that were drafted in his favor as long as the bailee does not stray away from the instructions in the bilateral agreement. C.P. Mills expresses the same view by stating that deviation in carriage of goods by sea has to be regarded on the same footing as in carriage of goods by land as well as in other bailment cases. ${ }^{93}$ Christopher M.C. Cashmore also contends that one cannot depart from general bailment theory when dealing with deviation on either land or sea. ${ }^{94}$ It is very important to note that neither Professor Coote nor C.P. Mills or Christopher M.C. Cashmore are opposing the orthodox view of Photo Productions v Securicor. C.P. Mills is of the opinion that it would be 'against the spirit of law' to say that deviation is still very relevant after the judgments in Photo Productions $v$ Securicor. ${ }^{95}$ However, the fact that these writers do not ignore the impact of bailment theory on the deviation doctrine might help in the attempt to grasp the reason why Lord Wilberforce chose to label deviation cases as 'sui generis'.

Needless to say that there would not be such a vast array of law literature on deviation doctrine if the 'sui generis' contention would be the accepted view. On the contrary, it is the view of the minority. Martin Dockray, ${ }^{96}$ John Livermore, ${ }^{97}$ Stephen Girvin, ${ }^{98}$ Charles Debattista ${ }^{99}$ and

\footnotetext{
${ }^{92}$ Brian Coote, 'The Second Rise and Fall of Fundamental Breach' (1981) 55 ALJ 788-790.

${ }^{93}$ Mills, 'The future of deviation in the law of the carriage of goods' (n 1) 587, 588.

${ }^{94}$ Cashmore, 'The legal nature of the doctrine of deviation' (n 1) 494, 495.

${ }^{95}$ Mills (n 1) 596.

${ }^{96}$ Dockray, 'Deviation: a doctrine all at sea?' (n 1) 98.

${ }^{97}$ Livermore, 'Deviation, Deck Cargo and Fundamental Breach' (n 1) 264, 265.

${ }^{98}$ Girvin, Carriage of Goods by Sea (n 12) 321.
} 
Simon Baughen ${ }^{100}$ clearly favor the notion that deviation rules should not be separated from the principles of general contract law. Charles Debattista strongly argues that the view which is based on bailment theory and is in favor of separating deviation doctrine from general contract law appears to be 'slightly too elegant for comfort'. He restricts Professor Coote's bailment explanation to the development of the doctrine and contends that it does not stretch as to give grounds for the survival of the doctrine. Simon Baughen follows the views exposed in Photo Productions $v$ Securicor and supports the amalgamation of deviation rules with general contract law. What is more, Simon Baughen concluded his article 'Does deviation still matter?' with a statement which not only undoubtedly answered the question in the affirmative but which might also be considered as one of the boldest statements on deviation doctrine. He was of the opinion that deviation rules should be 'speedily buried' and that any problem concerning geographical deviation 'should be dealt with by the ordinary law of contract'. To my mind, such a contention is too bold and out of date for two main of reasons. Firstly, the reasoning in the case Kenya Railways $v$ Antares Co Pte Ltd (The Antares Nos. $1 \& 2$ ), ${ }^{101}$ which is what led the learned writer to affirm the burial of deviation doctrine concerned non-geographical deviation (so called 'quasi-deviation') in the form of on-deck carriage. Therefore, the statement that all problems connected with a deviation from geographical course should now be read as to accommodate the reasoning in The Antares is not entirely accurate. Secondly, The Antares deals exclusively with a situation where Hague-Visby Rules apply and are silent on whether it extends as to cover carriage contracts to which Hague-Visby Rules do not have an imperative effect. Thirdly, the learned writer's article was published before a very similar decision in The Kapitan Petko Voivoda again focusing on non-geographical deviation where Longmore L.J. left the doors open if only slightly ajar for the deviation doctrine to survive. ${ }^{102}$

${ }^{99}$ Debattista, 'Fundamental Breach and Deviation in the Carriage of Goods by Sea' (n 1) 35, 36.

${ }^{100}$ Baughen, 'Does deviation still matter?' (n 1) 98.

${ }_{101}$ [1986] 2 Lloyd's Rep. 633; [1987] 1 Lloyd's Rep. 424(hereinafter - The Antares)

102 [2003] 2 Lloyd's Rep. 1, [13]-[15]. 
We are now left to consider whether there is a clear answer to the problems created by the deviation rules. A proven liaison between deviation and bailment might reinforce the opinion that deviation doctrine should be a separate body of law, however, as has been suggested by a number of law experts and judges, it is a far-fetched possibility. Norman Palmer takes the middle ground and acknowledges that there a certain elements of deviation that are characteristic of the bailment theory and there are those that are in doubt. ${ }^{103} \mathrm{He}$ asserts that the consequences which the bailee has to face after an unreasonable deviation are threefold. Firstly, after the deviation occurs the bailee becomes strictly liable for any damage to the goods. Held covered and liberty clauses are convenient tools for avoiding such a situation, however that does not deny the fact that these precautions were implemented as not to render the ship owner / bailee liable under the general rule of bailment. Secondly, unless otherwise agreed, upon the happening of an unjustified deviation the bailee is divested of the right of possession to the goods. Thirdly, unreasonable deviation is what triggers the cancellation of all exclusion or limitation clauses provided for in the agreement. Norman Palmer contends that first two consequences are unique to bailment, whereas the third one seems most likely to be of exclusively contractual nature. He goes on to conclude that the third consequence might signify the differences between the traditional deviation doctrine as per Hain and non-bailment contracts. The former recognises automatic discharge upon breach, while the latter is based on the rule that a repudiation does not have any legal effect until it is accepted by the innocent party. This is what Photo Productions $v$ Securicor was all about albeit unfortunately not in the realms of law on carriage of goods by sea.

Having considered the opinions expressed by various law experts, the only question left to answer is whether most recent (post-Photo Productions $v$ Securicor) court decisions have brought any light into the matter. The most important decisions are The Antares and The Kapitan Petko Voivoda. The common distinct feature of these cases is that the issue before the courts was one of non-geographical deviation. Nongeographical or quasi-deviation concept was first established in the United States of America where the courts came to a conclusion that

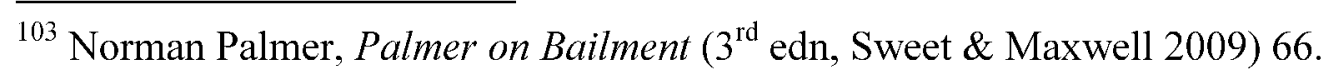


other types of breaches done by the ship owner could also amount to a deviation. ${ }^{104}$ Justification for such an extension of the doctrine could be based on the fact that any variation in the carriage of the cargo is subject to an increased risk and therefore might be rightfully called a deviation. While initially the American courts were inclined to limit quasi-deviation to unauthorized deck carriage, the US quasi-deviation doctrine has now been extended as to cover delay in delivery, unauthorized towage, intentional destruction and other breaches committed by the ship owner. ${ }^{105}$ The English cases in question concern deck carriage in breach of contract and package limitation under the Hague-Visby Rules. In The Antares the claimants argued that because there was no authorization to stow the goods on deck such a breach was of fundamental nature and therefore deprived the shipowners of the possibility to rely on the one year time bar provided for in Hague-Visby Rules article III, para 6. In this case Lloyd L.J. ${ }^{106}$ had no hesitation in concluding that the doctrine of fundamental breach does not exist anymore and that exception clauses cannot be cancelled out automatically. He affirmed the dicta found in Photo Productions $v$ Securicor that it all depends on the true construction of the contract and also favored the notion of assimilating deviation cases into general contract law. As to the question on the application of HagueVisby Rules Lloyd L.J. espoused the view that two main factors contribute to the end effect that article III, para 6 applies. ${ }^{107}$ The first one being of a formalistic nature that a wording 'whatsoever' which was missing from the Hague Rules ${ }^{108}$ article III makes the time limit applicable under the Hague-Visby Rules even in the event of deviation. The second contributing factor that led to the application of article III, para 6 was that Hague-Visby Rules have been given a force of law under the Carriage of Goods By Sea Act 1971 section 1(2).

The strength of the latter argument has to be weighed against the dicta of one older case of Stag Line Ltd v Fascolo Mango and Co Ltd

\footnotetext{
104 Theodora Nikaki, 'The Quasi-Deviation Doctrine' (2004) 35 Journal of Maritime Law \& Commerce 45, 48-50.

105 ibid 60-71.

${ }^{106}$ [1987] 1 Lloyd's Rep. 424, 429, 430.

107 ibid.

${ }^{108}$ International Convention for the Unification of Certain Rules of Law relating to Bills of Lading (adopted 25 August 1924, entered into force 2 June 1931) 120 LNTS 155 (Hague Rules).
} 
which dealt with the application of the Hague Rules and has never been overruled. ${ }^{109}$ In that case, the Court of Appeal held that the traditional doctrine of deviation survives even where the Hague Rules are applicable. While the force of law to the Hague-Visby Rules was given by the Carriage of Goods By Sea Act 1971 section 1(2) ${ }^{110}$, there were no such provisions in Carriage of Goods By Sea Act 1924. The fact that the latter edition of the Act was in force when Stag Line was decided persuaded the House of Lords to decide that deviation doctrine persisted even where the parties had chosen to incorporate Hague Rules into their bills of lading. ${ }^{111}$ Now why would anyone think this older case dealing with an earlier edition of the Hague Rules is of any significance today? Well, firstly, because this case was decided in the House of Lords, whereas The Antares is a decision of the Court of Appeal. Secondly, The Antares deals specifically with the imperative application of the HagueVisby Rules and leaves the question open as to whether the same approach applies to other situations. Thirdly, unlike The Antares which dealt with deck storage, Stag Line was actually a case about geographical deviation. I do not think it would be wrong to conclude that these factors raise a question as to the general application of The Antares to all aspects of deviation, more specifically the traditional geographical deviation.

These doubts were deepened further in The Kapitan Petko Voivoda. This was another case of the Court of Appeal on non-geographical deviation. While in parallel with The Antares it represents a strong move towards depriving deviation doctrine of any place in English law, we are left to wonder why the judges still do not make the final decision. The facts of the case are not as important as the finding of Longmore L.J. that deviation cases cannot be considered as a broad principle of general acceptation, 112 . He further contended that there is an important question of whether deviation rules 'exemplify even a principle of English law'. Such notions are of strong character and are in accordance with the view expressed by Lloyd L.J. in The Antares. However, that does not answer the query why Longmore L.J. concluded the reasoning by saying that it is

\footnotetext{
${ }^{109}$ [1932] AC 328.

${ }^{110}$ Carriage of Goods By Sea Act 1992 s 5(5) states that Hague-Visby Rules remain as a force of law.

111 [1932] AC 328, 342-343, 346-347.

112 [2003] 2 Lloyd's Rep. 1, [13]-[15].
} 
not that deviation principles do not exist anymore, but that the parties cannot attain any benefit from the 'supposed principle' in the matter at hand. It is undoubtedly clear that the lack of final judicial willpower and determination to sink the doctrine for good is what drives the controversy surrounding the deviation doctrine.

\section{E. CONClusion}

The ancient roots of the deviation doctrine are still talked about today. It cannot be said that a doctrine which survived for more than three centuries is of no relevance to the modern developments of maritime law. While Longmore L.J. in The Kapitan Petko Voivoda denied any chance of deviation doctrine being a 'broad principle of general application', the United States courts have broadened the doctrine to cover other breaches of contract as well. As far as English law is concerned, the introduction of liberty to deviate, held covered clauses have been triggered by the effect of deviation on shipping contracts. The theory on proper voyage route, justified and unjustified deviations without any doubt have an influence on deviations generally. In that respect the development of the doctrine on deviation cannot be written down to history books and left to dust as its importance cannot be denied.

A slightly different approach might be taken when talking about the consequences of an unreasonable deviation. Has the traditional deviation doctrine as it applies geographical deviation been completely abolished by Swiss Atlantique, Photo Productions v Securicor, The Antares and The Kapitan Petko Voivoda? The majority of law experts and the judiciary seem to think so. However, one cannot turn a Nelsonian blind eye to the doubts expressed by Lord Wilberforce in Photo Productions $v$ Securicor and Longmore L.J. in The Kapitan Petko Voivoda and also the works of law academics who support the notion that deviation might still have a beating heart. What is more, there has not been a decision as of yet in the Supreme Court (ex-House of Lords) concerning either quasi-deviation or geographical deviation that would bury all the hopes on the doctrine's continued survival. Can we then boldly state that deviation is a thing of the past? I would definitely agree with the views expressed by Christopher M.C. Cashmore in his reply article to Charles Debattista's 'Fundamental breach and deviation in the 
carriage of goods by sea' that there are still things left to consider and it cannot be that the House of Lords in Photo Productions $v$ Securicor had meant to overrule Orhis Steamship, Hain and Stag Line without even referring to them in any way. To my mind, that would be an astounding notion and I personally refrain from accepting it. 